Madrygal. Revista de Estudios Gallegos

ISSN: 1138-9664

\title{
Narrativa
}

\section{Bailar ben se baila un tango}

Vicente Araguas A Paula Cousillas Pena, porque ás veces
ten aires de verán na ollada
Liliana desfruta, noites de verán no Pimpín, poñendo unha torre de copas de champaña, de maneira que este, ao caer, faga unha pequena fervenza para ledicia dos que sentan na súa mesa, veraneantes sobre todo e algún empregado bancario, maiormente, desta pequena vila do Noroeste.

- Lili, eu quero outra cousa. Xa sabes que o champaña non me presta - dille o seu home, a faciana vermella por mor do alcol inxerido ao longo da tarde.

- Cala a boca, Marcialiño, que o coñac o inventou o demo - Liliana mira para Marcial con ollar carrancudo.

- Eu quero unha copa de Magno - teima o tipo, acenando á camareira para que veña onda el.

A noite preséntase morna, unha cousa rara nestes días nos que agosto se vai vencendo. Ao redor da mesa que preside Liliana, guapeteira de beleza antiga, como dunha desas películas que chaman de "celuloide reseso", a xente vai tomando posición, achegando cadeiras deica formar un segundo circo ou ringleira.

-Liliana, deixa que beba o que lle pete - o director da sucursal do Banco, bigotiño ao alférez provisional, chóscalle un ollo á muller nun xesto entre cómplice e sedutor.

— Vas durmir ti con el, Filucho? - a ironía da dona endoza unha resposta que, polo seu xesto, podería estar camuflando carraxes.
Da segunda ringleira que arrodea a mesa de Liliana sae unha voz ben afinada entoando unha canción da vila. Unha cantiga que fala de tres mulleres que pois ían de romaría decidiran argallar unha boa merenda. E cando andaban a preparala, o demo do viño polo medio, veu o marido dunha delas e deu paus nelas todas tres. E ao nachiño que encetou a boroa do canto xa se lle están unindo outros comensais. Entre eles Marcial, termando da segunda copa de Magno da noite. E canta ben Marcial por máis que cargando os erres en exceso, cousa que alporiza de máis a unha das donas presentes. Esa que, sendo pitoña e non querendo -coquetapoñer lentes, preme, enruga os ollos ata formar con eles unha raia como de óptica chinesa. E agora xa todos cantan, os que o fan mellor agachando as voces dos desafinados. Que pois se deixan levar dos que si saben coidan cantar con xeito. Cal eses bailaríns pouco peritos empurrados na danza polos bailóns sabedores e sabidos. Algo así.

-A noite é nova! Todos a bailar! — berra Marcial pedíndolle música, e unha terceira copa de Magno, á camareira, ollos bonitos, tocados por unha certa tristura e a canseira de servir copas a esta preada de veraneantes mamalóns e, de cando en vez, mamados.

-E que música quere, Don Marcial? —di a cativa, a man esquerda termando da bandexa, a dereita, apoiada na perna. O mandil que a cobre tan branco como a lúa de Cetárea a estas horas. 
- Un tango iría ben —o home apura a copa e cun clandestino aceno, polgar abaixo, xa está pedindo outra.

No aire da vila estoupa un aire tangueiro. Unha orquestra ben ligada na que sobrancea un bandoneón que dá paso a unha voz de home, fermosa, ben temperada, que ule a loción para despois do barbeado. Unha voz que fala dunha casa na que hai de todo, de todo para amar, e mesmo o gato, para que non altere os amantes coas súas miañaduras, é de porcelana. Esas cousas.

—Préstalle esta música, Don Marcial? _ pregunta a camareira.

—E logo, que levas na cabeza? —inquire o home, a lingua xa zoupona de máis, reparando que a moza vai toucada agora cun estraño bonete, con forma de batel invertido, no que se ve a cara dun limón a sorrir e no que pon Schuss.

-Unha ghorra, home!

-Pensei que era un ghato...

Un pouco máis adiante do corro de veraneantes, e algún vencellado da vila, non pescadores ou pescantinas alleos a esta troula, andarán nas súas tarefas ou -máis seguro-a durmir, no espazo entre a terraza e a beirarrúa Liliana e Filucho bailan o tango. O seu, na baila, é un xeito elegante e seguro, marcando moi ben as figuras, con Lili dominando o acto e Filucho facendo con rigor o contrapunto. A abertura da saia de Liliana, á altura do xeonllo, fai que a bailona mesmo faga virgalladas á hora de apreixar co peroné a tibia do seu compañeiro de danza, vestido este cun pantalón beis, a xogo coa pescadora color crema que debería de protexelo da friaxe da madrugada. Por máis que a de hoxe, xa se dixo, veña morna.

- Teño medo, Lili - musita o bancario no oído da bailarina.

-Medo de que?

-Do teu home.

-Desa cousa? Mira, facendo o pallaso coma de costume.

Marcial baila só, coa copa nunha man, a outra contra do bandullo, non se sabe se para termar deste ou para finxir que aperta unha inexistente compañeira de baile.

-Dale, Marcial, dale - berra unha arxentina de paso pola vila, aloxada no Saint-Tropez.
- Bravo, Marcialiño, grande - bourea un nacho alto e lanzal quen con man tremante sostén unha garrafa de whisky, da que bebe a morro, en grolos longos.

Marcial olla, alporizado para a parella que baila con rigor o tango proposto polo Pimpín, e vai achegarse a eles, no seu baile senlleiro e delirante. Liliana óllao de esguello con desprezo. Filucho fai o mesmo pero cunha certa preocupación. Porque, sábeo ben, con maridos ciumentos mellor non tratar en exceso. $\mathrm{O}$ suxeito alto arranca agora cunha canción mexicana que fala dun tipo que se define como soldado, mais non calquera, senón de levita, de esos de caballería. O tipo alto gasta cinto con fibela dourada e vaqueiros cinguidos que fan aínda máis longas unhas pernas de seu cumpridas. O langrán profire rechouchíos nada afinados que por momentos semellan un cacarexar derramado.

—Non darás calado, Tío Tom? — dille unha rapaza que con el viñera e que no seu rostro de fastío semella ter aturado moitas veces esta parrandada.

—E logo, non canto ben? —o chamado Tío Tom semella contrito logo de interromper a súa melopea.

Outro é o tango o que enche de melancolías e barrios plateados por la luna a noite, cor nata, pola luz dos faroliños do Pimpín, marelo suave e a lúa, tan tépeda, tan branca. E Liliana e Filucho bailan con brío, ollándose con ollos de caramelo. Marcial senta nunha cadeira preto deles, a cabeza anicada, un pano de papel represando o sangue que lle verque do nariz logo de que zoupase, caendo no chan da terraza, ao tentar un paso de baile con el mesmo. Os concorrentes van deixando o lugar, camiño quen sabe onde que a noite, como berrara Marcial, aínda é nova. A camareira, na porta do Pimpín, raña na cabeza, destoucada xa do bonete que semella un batel invertido e pensa «que que tropiña de veraneantes», que desertarán axiña remate agosto, e daquela virán pescadores e pescantinas e sempre, sempre Don Filucho, co seu bigotiño, a lle facer as beiras. A ela, tan ciumenta agora mentres ve como as meixelas dos dous que bailan tangos van tan pegadiñas como as lapas contra das rochas.

Majadahonda, abril, 2019 